Hal. $170-181$

\title{
PENGARUH NEGARA ASAL TERHADAP NIAT PEMBELIAN MELALUI CITRA MEREK OLEH KONSUMEN SEPATU DI KOTA BANDUNG
}

\author{
Salma Fauziyyah \\ Fakultas Ekonomi dan Bisnis, Universitas Jember \\ salmafauziyyah@gmail.com \\ Mohamad Dimyati \\ Fakultas Ekonomi dan Bisnis, Universitas Jember \\ dim_ekounej@yahoo.co.id \\ Ika Barokah Suryaningsih \\ Fakultas Ekonomi dan Bisnis, Universitas Jember \\ barokah.feb.unej.ac.id
}

\begin{abstract}
Today's consumers are very critical in making choices for the shoes products by considering the intrinsic and extrinsic factors of the products which one of them is the country of origin of the product brand. The purpose of this study is to analyze the influence of country of origin on the purchase intention through brand image of the shoes products for the consumers in Bandung City. The population of this research is the shoes consumers in Bandung City. The sample consists of 125 respondents taken by purposive sampling approach. The method of analysis used in this study is Structural Equation Modeling (SEM). The results indicate that country of origin influences brand image, brand image influences purchase intention, but there is no direct influence of country of origin on purchase intention of the shoes product in Bandung City.
\end{abstract}

Keywords: Country of Origin, Brand Image, Purchase Intention.

\begin{abstract}
Abstrak: Konsumen saat ini sangat kritis dalam memilih produk sepatu dengan berbagai pertimbangan baik dari segi intrinsik maupun ekstrinsik produk yang salah satunya adalah negara asal merek produk. Tujuan penelitian ini adalah untuk menganalisis pengaruh negara asal terhadap niat pembelian melalui citra merek produk sepatu oleh konsumen di Kota Bandung. Populasi penelitian ini adalah konsumen sepatu di Kota Bandung. Sampel penelitian sebanyak 125 responden yang diambil dengan pendekatan purposive sampling. Metode analisis yang digunakan adalah SEM. Hasil penelitian menunjukkan bahwa negara asal memiliki pengaruh terhadap citra merek, citra merek memiliki pengaruh terhadap niat pembelian, namun tidak terdapat pengaruh langsung antara negara asal terhadap niat pembelian konsumen sepatu di Kota Bandung.
\end{abstract}

Kata kunci: Negara Asal, Citra Merek, Niat Pembelian.

\section{Pendahuluan}

Persaingan di pasar global telah mendorong perusahaan-perusahaan multinasional semakin memperluas jaringannya ke seluruh dunia untuk memperluas pangsa pasarnya. Perusahaan multinasional yang berusaha menyaingi pesaing mereka di pasar dunia telah semakin aktif melintasi batas-batas nasional mereka untuk membawa keuntungan strategis bagi operasi mereka.Sebagai konsekuensi 
dari globalisasi, produk yang diproduksi maupun dipasarkan di lebih dari satu negara merupakan hal yang biasa.

Evaluasi konsumen terhadap suatu produk dalam ilmu perilaku konsumen berdasarkan informasi intrinsik meliputi konten dan desain produk tersebut, sementara evaluasi terhadap informasi ekstrinsik meliputi harga, merek, maupun negara asal produk tersebut (Engel et al., 1994:175-178). Sebelum menentukan produk yang akan dibeli untuk sebagian konsumen akan melihat dari mana asal produk tersebut diproduksi. Negara asal suatu produk dapat menimbulkan persepsi kualitas baik buruknya produk yang bersangkutan.Negara asal suatu produk tersebut disebut dengan istilah Country of Origin yang secara umum dianggap sebagai bagian dari karakteristik suatu produk.

Salah satu aspek yang sering kali dijadikan acuan yang terkait dengan negara asal adalah dengan citra merek suatu produk. Citra merek merupakan seperangkat keyakinan, ide, kesan yang dimiliki sesorang terhadap suatu merek (Simamora, 2004:59). Konsumen sering kali mengaitkan negara asal dengan citra merek produk yang akan dibelinya. Hal tersebut menunjukkan bahwa negara asal suatu produk dapat memengaruhi citra merek produk tersebut.Beberapa peneliti menghasilkan model yang mendukung pengaruh negara asal terhadap citra merek (Aysan et al., 2016; Permana \& Haryanto, 2014; Tulipa \& Muljani, 2015).Citra merek yang baik merupakan hal penting yang harus dimiliki perusahaan karena dapat menjadi dasar untuk memengaruhi niat pembelian konsumen. Citra merek memiliki pengaruh positif terhadap niat beli konsumen (Diamantopoulos et al., 2011; Fakharmanesh \& Miyandehi, 2013; Tulipa \& Muljani, 2015; Yanthi \& Jatra, 2015). Konsumen seringkali memiliki preferensi terhadap suatu merek atau perusahaan karena citranya. Niat pembelian merupakan suatu tahap penting yang harus diperhatikan oleh para pemasar karena hal tersebut adalah suatu kondisi yang mendahului sebelum individu mempertimbangkan atau membuat keputusan dalam memilih sebuah produk. Penelitian Permana \& Haryanto (2014) menunjukkan inkonsistensi dimana citra merek tidak memengaruhi niat pembelian konsumen.

Dunia fashion dekat dengan kehidupan masyarakat sehari-hari. Setiap hari masyarakat tidak lepas dari kebutuhan sandang baik sebagai kebutuhan pokok maupun kebutuhan sebagai penunjang penampilan. Sepatu dapat menunjang keindahan pakaian yang dikenakan selain untuk melindungi kaki. Sepatu sudah bukan menjadi salah satu kebutuhan tambahan saja, namun bagi beberapa orang 
sepatu sudah menjadi kebutuhan utama atau bahkan sebagai aset yang berharga. Sepatu dapat digunakan untuk menampilkan citra seseorang.Sepatu juga dapat menambah kepercayaan diri konsumen yang menggunakannya. Orang yang menginginkan prestige akan mencari produk sepatu yang lebih berkelas dan mahal. Salah satu kota yang terkenal sebagai kota berindustri sepatu di Indonesia adalah kota Bandung. Kota yang memiliki julukan Paris van Java ini sudah terkenal dengan fashion-nya. Banyak factory outlet dan distribution outlet sepatu yang terdapat di Kota Bandung yang menawarkan produk dengan kualitas bagus dengan harga terjangkau.

Produk sepatu luar negeri di Indonesia memiliki pasar yang cukup besar. Berdasarkan TOP Brand Award Indonesia Fase 2 Tahun 2016 (Award, 2016), terdapat sepuluh merek sepatu terbaik yang berasal dari merek dalam negeri dan merek luar negeri. Merek terbaik tersebut termasuk dalam empat kategori sepatu, yaitu sepatu olah raga, sepatu kerja, sepatu sandal, dan sepatu sekolah. Sepuluh merek sepatu tersebut meliputi Adidas (Jerman), Nike (AS), Bata (Swiss), Yongki Komaladi (Indonesia), Fladeo (Indonesia), Converse (Amerika), Eiger (Indonesia), Carvil (Indonesia), Buccheri (Indonesia), dan Reebok (Amerika). Hal tersebut menunjukkan bahwa sepatu luar negeri dapat bersaing secara ketat dengan sepatu buatan Indonesia.

Persaingan ketat antar merek luar negeri dan dalam negeri tersebut menuntut perusahaan terus mempertimbangkan motivasi konsumen dalam membeli produknya. Kualitas produk yang dirasakan adalah masalah penting dalam pengembangan dan implementasi strategi pemasaran yang bertujuan untuk membangun citra merek dan meningkatkan pangsa pasar.

Penelitian mengenai dampak negara asal dan citra merek dalam membangun niat pembelian konsumen sepatu di Kota Bandung perlu dilakukan berdasarkan pertimbangan terkait fenomena yang terjadi serta ketidakkonsistenan hasil penelitian terdahulu. Tujuan penelitian ini adalah: (1) menguji pengaruh negara asal terhadap citra merek sepatu di Kota Bandung; (2) menguji pengaruh citra merek terhadap niat pembelian konsumen sepatu di Kota Bandung; (3) menguji pengaruh negara asal terhadap niat pembelian konsumen sepatu di Kota Bandung; (4) mengetahui peran mediasi citra merek terhadap hubungan negara asal dan niat pembelian konsumen sepatu di Kota Bandung. 


\section{Metodologi}

Penelitian ini merupakan confirmatory research dan explanatory research. Penelitian konfirmatori penelitian ini adalah menguji hipotesis antar variabel negara asal, citra merek dan niat pembelian yang dihipotesiskan. Penelitian eksplanatori dilakukan dalam hal menjelaskan model keterkaitan antar variabel penelitian yang dihasilkan. Penelitian ini bertujuan untuk menganalisis dampak negara asal dalam membangun niat pembelian konsumen sepatu di Kota Bandung dengan mediasi citra merek.

Populasi penelitian ini adalah keseluruhan konsumen produk sepatu di Kota Bandung, Jawa Barat. Jumlah anggota populasi tidak diketahui karena tidak terdapat data mengenai jumlah konsumen sepatu di Kota Bandung.Teknik pengambilan sampel dalam penelitian ini menggunakan teknik non probability sampling dengan pendekatan purposive sampling yang mensyaratkan kriteria tertentu.Alasan penggunaan teknik tersebut adalah karena jumlah anggota populasi yang tidak diketahui. Pengambilan sampel berdasarkan kriteria sebagai berikut:

a. Konsumen sepatu yang berdomisili di Kota Bandung.

b. Pernah membeli sepatu baik produk bermerek dalam negeri atau luar negeri.

C. Memiliki pengetahuan tentang negara asal dari produk sepatu yang dibelinya.

Analisis data yang digunakan untuk menjawab rumusan masalah dalam penelitian ini adalah metode persamaan struktural (Structural Equation Modelling SEM) dengan model moderasi, oleh karena itu besarnya ukuran sampel memiliki peran penting dalam intepretasi hasil. Metode SEM memungkinkan untuk digunakan dalam menganalisis model-model dengan variabel terobservasi serta variabelvariabel laten serta kemudahannya dalam membantu peneliti melakukan analisisanalisis multivariat berjenjang secara simultan (Ferdinand, 2014:4). Ferdinand (2014b:62) menyebutkan bahwa ukuran sampel yang harus dipenuhi dalam pemodelan SEM adalah minimal 100, dengan demikian ukuran sampel dalam penelitian ini adalah 125.

\section{Hasil dan Pembahasan}

$\underline{\text { Hasil }}$

Model yang telah terbentuk dijadikan sebagai acuan dalam pengujian hipotesis.Secara umum, pengujian hipotesis dilakukan dengan menganalisis nilai critical ratio (C.R) dan nilai probabilitas $(P)$ yang ditunjukkan pada Tabel 1, dibandingkan dengan batasan statistik yang disyaratkan. Nilai yang dipersyaratkan 
adalah critical ratio diatas 1,96 dan nilai probabilitas di bawah 0,05. Jika hasil dari pengolahan data memenuhi persyaratan tersebut, maka hipotesis yang diajukan dinyatakan dapat diterima. Interpretasi masing-masing hipotesis adalah sebagai berikut.

Berdasarkan hasil pengujian Goodness of Fit yang menghasilkan sebagian besar kriteria yang terpenuhi maka dapat disimpulkan bahwa model tersebut dapat diterima dengan baik. Tahap selanjutnya adalah menguji kausalitas sesuai hipotesis yang telah dikembangkan. Hasil pengujian kausalitas dari Full Model dengan modifikasi ditunjukkan pada Tabel 1.

Tabel 1. Hasil Pengujian Kausalitas

\begin{tabular}{ccccc}
\hline Hipotesis & $\begin{array}{c}\text { Koefisien } \\
\text { Jalur }\end{array}$ & CR & Probabilitas & Keterangan \\
\hline $\mathrm{BI}\left(\mathrm{Y}_{2}\right) \leftarrow \mathrm{COO}\left(\mathrm{X}_{1}\right)$ & 0,707 & 6,300 & ${ }^{\star \star \star}$ & Signifikan \\
\hline $\mathrm{PI}\left(\mathrm{Y}_{3}\right) \leftarrow \mathrm{COO}\left(\mathrm{X}_{1}\right)$ & $-0,106$ & $-1,041$ & 0,298 & Tidak Signifikan \\
\hline $\mathrm{PI}\left(\mathrm{Y}_{3}\right) \leftarrow \mathrm{BI}\left(\mathrm{Y}_{2}\right)$ & 0,131 & 2,154 & 0,031 & Signifikan \\
\hline
\end{tabular}

Sumber: Data primer diolah

Keterangan: ${ }^{* * *}$ menunjukkan nilai lebih kecil dari 0,001

Tabel 1 menunjukkan bahwa dari tiga hipotesis terdapat dua hipotesis yang memenuhi syarat dalam uji kausalitas yaitu memiliki CR lebih besar dari 1,96 dan probabilitas yang lebih kecil 0,05 , namun juga terdapat satu hipotesis dengan probabilitas yang lebih besar dari 0,05 serta CR yang lebih kecil dari 1,96 yaitu pada pengaruh Negara Asal $\left(\mathrm{X}_{1}\right)$ terhadap Niat Pembelian $\left(\mathrm{Y}_{3}\right)$. Hasil tersebut yang menjadi dasar dalam pembahasan hipotesis.Masing-masing hipotesis tersebut dibahas secara terperinci sebagai berikut.

1. Uji Hipotesis 1

Hipotesis pertama dalam penelitian ini adalah negara asal berpengaruh terhadap citra merek sepatu di Kota Bandung sehingga semakin tinggi persepsi konsumen terhadap negara asal produk sepatu maka semakin tinggi pula persepsi citra merek sepatu oleh konsumen, demikian pula sebaliknya. Hasil olah data menunjukkan bahwa nilai C.R sebesar 6,300 dan nilai $P$ lebih kecil dari 0,001. Nilai yang diperoleh telah memenuhi syarat pada uji hipotesis dimana nilai C.R berada di atas 1,96 dan nilai $P$ berada di bawah 0,050 . Hal ini berdampak pada diterimanya hipotesis kedua penelitian ini.

2. Uji Hipotesis 2

Citra merek berpengaruh terhadap niat pembelian konsumen sepatu di Kota Bandung merupakan hipotesis kedua penelitian ini. Hal ini memiliki makna bahwa 
semakin tinggi persepsi konsumen akan citra merek produk sepatu maka akan berdampak pada semakin tinggi pula untuk terbentuknya niat pembelian konsumen dan begitu pula sebaliknya. Hasil penelitian menunjukkan nilai dari C.R sebesar 2,154 (di atas 1,96) dan nilai $P$ sebesar 0,031 (di bawah 0,05). Hasil tersebut mengindikasikan bahwa kedua syarat yang digunakan dalam uji hipotesis telah terpenuhi sehingga hipotesis ketiga penelitian ini dapat diterima.

\section{Uji Hipotesis 3}

Hipotesis ketiga pada penelitian ini adalah negara asal berpengaruh terhadap niat pembelian konsumen sepatu di Kota Bandung sehingga semakin tinggi persepsi konsumen akan negara asal produk sepatu maka semakin tinggi pula niat pembelian konsumen, begitu pula sebaliknya. Berdasarkan hasil pengolahan data diketahui bahwa nilai C.R dari pengaruh variabel negara asal terhadap kepuasan adalah 1,041; dengan nilai $P$ sebesar 0,298 (di atas 0,05 ). Kedua nilai ini menunjukkan hasil yang tidak memenuhi syarat, yaitu diatas 1,96 untuk C.R dan kurang dari 0.05 untuk nilai P. Kondisi ini dapat dinyatakan bahwa hipotesis kelima dalam penelitian ini tidak dapat diterima.

Penelitian pada konsumen sepatu Kota Bandung ini memiliki karakteristik responden yang beragam baik dari segi usia, jenis kelamin, pendapatan/uang saku per bulan, maupun dari jenis sepatu yang digunakannya. Karakteristik responden berdasarkan jenis kelamin didominasi oleh wanita dengan tingkat usia pada $>43$ tahun, pendapatan/uang saku terbanyak berada pada rentang $>\mathrm{Rp} 2.000 .000$ dengan merek yang digunakan mayoritas merek luar negeri.

Berdasarkan model yang dibentuk, hasil penelitian menunjukkan bahwa dua hipotesis penelitian diterima dan satu hipotesis penelitian tidak diterima. Interpretasi hasil penelitian menggambarkan bahwa terdapat pengaruh antara Negara Asal terhadap Citra Merek dan antara Citra Merek terhadap Niat Pembelian. Sementara itu, terbukti tidak terdapat pengaruh langsung antara Negara Asal terhadap Niat Pembelian konsumen sepatu di Kota Bandung. Hasil perhitungan efek mediasi menunjukkan bahwa terdapat pengaruh tidak langsung Negara Asal terhadap Niat Pembelian melalui Citra Merek.

\section{Relasional antara Negara Asal dan Citra Merek}

Penelitian ini menghasilkan model hubungan Negara Asal dengan Citra Merek yang dijadikan sebagai acuan dalam pengujian hipotesis. Pengujian hipotesis membuktikan bahwa terdapat pengaruh positif dan signifikan antara negara asal 
merek terhadap citra merek oleh konsumen akan kualitas sepatu di Kota Bandung. Hasil ini menunjukkan bahwa semakin seorang konsumen menganggap citra suatu negara asal merek itu positif, maka akan menciptakan citra merek yang baik pula pada produk tersebut.

Negara asal dapat memengaruhi citra merek suatu produk, dengan demikian semakin bagus persepsi konsumen terhadap negara asal produk maka semakin bagus pula persepsi konsumen akan citra merek tersebut (Mostafa, 2015; Permana \& Haryanto, 2014; Tulipa \& Muljani, 2015). Hal tersebut mengindikasikan bahwa konsumen mengaitkan negara asal dengan citra merek produk sepatu yang akan dibelinya. Fenomena ini semakin memperkuat bahwa negara asal produk memberikan kontribusi yang baik pada proses pembentukan citra suatu merek sepatu di Kota Bandung. Hasil penelitian juga sejalan dengan teori dimana terdapat konsensus umum bahwa negara asal berhubungan dengan citra merek (Tjiptono, 2008:352). Negara asal memengaruhi pesepsi dan citra di benak konsumen. Konsumen cenderung memiliki kesan tertentu terhadap suatu produk yang dihasilkan di suatu negara.

\section{$\underline{\text { Relasional antara Citra Merek dan Niat Pembelian }}$}

Penelitian ini menghasilkan model hubungan Citra Merek dengan Niat Pembelian yang dijadikan sebagai acuan dalam pengujian hipotesis. Hasil yang diperoleh membuktikan bahwa terdapat pengaruh positif dan signifikan antara citra merek terhadap niat pembelian konsumen sepatu di Kota Bandung. Hasil ini menunjukkan bahwa semakin seorang konsumen menganggap citra merek itu positif, maka akan menciptakan niat pembelian pada produk tersebut.

Pada pengujian hipotesis ini ditemukan bahwa citra merek mampu menarik konsumen untuk melakukan suatu proses pembelian. Hal ini sejalan dengan pendapat Setiadi (2003:216) yang menyatakan bahwa minat beli dibentuk dari sikap konsumen terhadap produk yang terdiri dari kepercayaan konsumen terhadap merek dan evaluasi merek, sehingga dari dua tahap tersebut maka muncul minat untuk membeli. Citra merek yang baik akan membuat konsumen pun yakin dengan merek tersebut dan akan menggunakan produk dari merek tersebut (Simamora, 2004:124). Hasil penelitian juga sejalan dengan penelitian terdahulu yang menunjukkan bahwa citra merek suatu produk berpengaruh positif terhadap niat pembelian (Diamantopoulos et al., 2011; Fakharmanesh \& Miyandehi, 2013; Tulipa \& Muljani, 2015; Yanthi \& Jatra, 2015). 


\section{Relasional antara Negara Asal dan Niat Pembelian}

Berdasarkan hasil pengolahan data, negara asal tidak berpengaruh positif terhadap niat pembelian.Fenomena tersebut menunjukkan bahwa negara asal merek bukan menjadi faktor penentu niat pembelian konsumen secara langsung. Hasil penelitian ini tidak sejalan dengan pendapat Tjiptono (2008:352) yang menyatakan bahwa pengaruh atau citra negara produsen suatu produk sangat menentukan keputusan pembelian konsumen. Hasil penelitian terdahulu yang tidak memberikan dukungan bahwa tidak terdapat pengaruh langsung yang positif antara negara asal dengan niat pembelian adalah Li et al. (2012); Martinelli et al. (2012); Permana \& Haryanto (2014); Rahaman (2014); dan Yanthi \& Jatra (2015). Hasil penelitian ini menemukan bahwa negara asal belum mampu menarik calon konsumen untuk melakukan suatu proses pembelian. Ini menandakan dalam suatu proses pengambilan keputusan, negara asal produk sepatu dirasa belum cukup kuat untuk mendorong konsumen untuk melakukan pembelian.

Peran Mediasi Citra Merek terhadap Hubungan Negara Asal dan Niat Pembelian

Hasil penelitian menunjukkan terdapat pengaruh tidak langsung negara asal terhadap niat pembelian melalui variabel citra merek. Hal ini ditunjukkan dari pengaruh tidak langsung melalui citra merek yang lebih besar daripada pengaruh langsungnya. Pengaruh tidak langsung yang dimaksud bermakna bahwa seorang calon konsumen menganggap bahwa produk atau barang yang berasal dari negara lain memiliki citra merek yang lebih baik daripada produk dalam negeri.

Hasil penelitian mengindikasikan bahwa semakin tinggi inovasi serta kreativitas desain produk yang dimiliki suatu negara maka lambang atau logo produk sepatu tersebut akan semakin mudah diingat oleh konsumen sepatu di Kota Bandung. Inovasi serta kreativitas desain produk suatu negara yang tinggi juga akan membuat merek produk sepatu tersebut mudah untuk dikenali konsumen. Semakin kreatif dan inovatif negara asal produk maka semakin tinggi image atau citra konsumen sepatu di Kota Bandung.

Kemajuan teknologi yang tinggi dan kualitas produk yang dimiliki suatu negara dapat meningkatkan citra merek yang merupakan representasi dari keseluruhan persepsi konsumen sepatu di Kota Bandung akan label atau nama produk sepatu yang meliputi lambang maupun logo produk sepatu yang digunakannya, serta citra atau image pengguna. Peningkatan citra merek tersebut selanjutnya akan meningkatkan niat konsumen sepatu di Kota Bandung untuk membeli produk sepatu 
tersebut sebelum melakukan transaksi pembelian. Semakin tinggi citra merek produk sepatu maka akan membut konsumen semakin berkeinginan, berharap, dan berencana untuk membeli produk tersebut. Konsumen juga akan mengganti produk lamanya yang telah rusak atau apabila memiliki uang dengan merek sepatu yang bersangkutan. Fenomena ini sesuai dengan hasil penelitian Diamantopoulos et al. (2011) yang menunjukkan bahwa terdapat dampak secara tidak langsung antara citra negara asal pada niat pembelian dimana pengaruhnya sepenuhnya dimediasi oleh citra merek.

Citra negara asal merek sepatu sebagai negara maju serta tingginya prestise yang dimiliki negara asal akan semakin mempermudah konsumen di Kota Bandung dalam mengingat lambang atau logo produk sepatu yang kemudian akan meningkatkan rencana, harapan, dan keinginan konsumen untuk membeli produk tersebut. Hal tersebut juga akan mempermudah pengenalan merek produk sepatu yang bersangkutan sehingga konsumen memiliki niat untuk membeli produk tersebut apabila memiliki uang atau sebagai pengganti sepatu yang telah rusak. Prestise dan citra negara maju yang dimiliki negara asal produk sepatu akan membuat konsumen semakin memiliki citra atau image yang tinggi yang membuat konsumen berniat untuk membeli produk tersebut.

Konsumen di Kota Bandung tidak memandang negara asal dari suatu produk adalah hal yang substansial, keadaan ini dicirikan dengan hasil penelitian yang menerangkan bahwa kontribusi negara asal terhadap niat pembelian tidak signifikan. Hal tersebut menunjukkan bahwa konsumen sepatu di Kota Bandung tidak sensitif akan negara asal sebuah produk terutama produk sepatu, sehingga perusahaan multinasional maupun global yang datang dari negara yang dirasa memiliki citra baik dapat dengan mudah diterima di pasar Indonesia. Peran merek sangat penting bagi produk terutama produk multinasional karena merek merupakan salah satu senjata untuk dapat berkompetisi di perdagangan global. Hasil penelitian menunjukkan bahwa apabila konsumen hanya melihat dari negara asal merek maka niat pembelian konsumen tidak akan terbentuk. Niat pembelian konsumen dibangun bukan hanya dengan melihat negara asal merek secara langsung tetapi harus melalui citra merek yang bersangkutan. Selama negara asal merek tidak menimbulkan citra merek yang bagus di benak konsumen maka negara asal merek tersebut tidak akan memengaruhi niat konsumen untuk membeli. Niat pembelian konsumen akan kuat hanya apabila konsumen memiliki preferensi terhadap negara tertentu, misalnya Adidas dan Nike 
yang berasal dari Amerika menciptakan citra merek yang bagus bagi konsumen. Fenomena tersebut menunjukkan bahwa citra merek menjadi mediator sempurna antara negara asal merek sepatu dengan niat pembelian konsumen di Kota Bandung.

Berdasarkan hasil penelitian serta pembahasan masing-masing relasional antar variabel, maka didapatkan model akhir seperti yang ditunjukkan pada Gambar 1.Perbedaan model yang diajukan dengan model akhir tersebut adalah ketiadaan garis regresi antara negara asal dengan niat pembelian. Hal tersebut berarti tidak terdapat hubungan langsung dari negara asal produk sepatu terhadap niat pembelian konsumen sepatu di Kota Bandung.

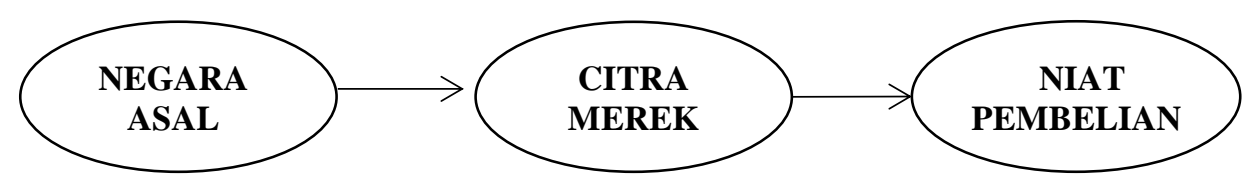

Gambar 1. Diagram Jalur Full Model Akhir

\section{Kesimpulan}

Kesimpulan yang dapat diambil berdasarkan hasil analisis data serta interpretasi hasil adalah: (a) Negara asal berpengaruh terhadap citra merek sepatu di Kota Bandung. Hal tersebut menunjukkan bahwa semakin seorang konsumen mempercayai citra suatu negara asal merek itu positif, maka akan menciptakan citra merek yang baik pula pada produk tersebut; (b) Citra merek berpengaruh terhadap niat pembelian konsumen sepatu di Kota Bandung. Kesimpulan yang dapat diambil adalah semakin baik persepsi konsumen akan citra merek suatu produk, maka akan semakin besar niat pembelian konsumen pada produk tersebut; (c) Negara asal tidak berpengaruh terhadap niat pembelian konsumen sepatu di Kota Bandung. Hal ini mengindikasikan bahwa persepsi konsumen akan negara asal suatu produk tidak secara langsung menimbulkan niat pembelian konsumen pada produk tersebut.

\section{Saran}

Berdasarkan pada kesimpulan hasil penelitian ini, maka saran bagi manajemen perusahaan sepatu khususnya di wilayah Kota Bandung serta industri sejenis di Indonesia adalah manajemen pemasaran perusahaan sebaiknya mempertimbangkan pengaruh negara asal dan citra merek dalam membangun niat pembelian konsumen. Implikasi manajerial dari artikel ini adalah perusahaan harus dapat menghadapi strategi kompetitif dari berbagai negara. Mereka juga harus mempertimbangkan citra negara asalnya dan kemudian mengembangkan strategi 
bersaing yang paling tepat ketika perusahaan mempromosikan produk mereka ke pasar global. Jika suatu negara memiliki citra yang baik, maka perusahaan akan mendapatkan keuntungan dari pemasaran internasional. Jika tidak, maka strategi pemasaran perusahaan harus fokus pada atribut dari fitur produk yang bersangkutan atau melakukan strategi lain dalam rangka mengurangi pengaruh negatif yang disebabkan oleh citra negara yang buruk.

Sedangkan saran bagi peneliti selanjutnya diharapkan dapat menambah jumlah sampel untuk mendapatkan model yang lebih baik khususnya dalam penelitian bidang manajemen pemasaran terkait hubungan antara negara asal, citra merek, dan niat pembelian.

\section{Daftar Referensi}

Award, T.B., 2016.Top Brand Index 2016 Fase 2. Available at: http://www.topbrandaward.com/top-brand-survey/survey-result/top_brand_index_2016_fase_2 [Accessed January 20, 2017].

Aysan, A.F. et al., 2016. Is Small The New Big? Islamic Banking For Smes In Turkey. Economic Modelling, 54, pp.187-194.

Diamantopoulos, A., Schlegelmilch, B. \& Palihawadana, D., 2011. The Relationship Between Country-Of-Origin Image and Brand Image as Drivers of Purchase Intentions: A Test Of Alternative Perspectives. International Marketing Review, 28(5), pp.508-524.

Engel, J.F., Blackwell, R.D. \& Miniard, P.W., 1994. Perilaku Konsumen, edisi ke-6., Jakarta: Binarupa Aksara.

Fakharmanesh, S. \& Miyandehi, R.G., 2013. The Purchase of Foreign Products: The Role of Brand Image, Ethnocentrism and Animosity: Iran Market Evidence. Iranian Journal of Management Studies, 6(1), pp.145-160.

Ferdinand, A., 2014a. Metode Penelitian Manajemen: Pedoman Penelitian untuk Penulisan Skripsi Tesis dan Disertasi IImu Manajemen, edisi ke-5. Semarang: BP Universitas Diponegoro.

Ferdinand, A., 2014b. Structural Equation Modeling dalam Penelitian Manajemen, edisi ke-5. Semarang: Undip Press.

Martinelli, E. et al., 2012. The COO Effect and the Role of Ethnocentrism on Consumer Buying Behavior. Conference Paper at 41th EMAC Conference, At Lisbon (Portugal).

Mostafa, R.H.A., 2015. The Impact of Country of Origin and Country of Manufacture of a Brand on Overall Brand Equity. International Journal of Marketing Studies, 7(2), pp.70-83.

Permana, M.S. \& Haryanto, J.O., 2014.Pengaruh Country of Origin, Brand Image dan Persepsi Kualitas terhadap Intensi Pembelian.Jurnal Manajemen, 18(3), pp.365380. 
Rahaman, A., 2014. An Interactive Influence of Country of Origin on buying Intention of Branded Clothing: A Study on Female Brand. Global Journal of Management and Business Research: E Marketing, 14(2), pp.21-30.

Setiadi, N.J. 2003. Perilaku Konsumen: konsep dan Implikasi untuk Strategi dan Penelitian Pemasaran. Jakarta: Prenada Media.

Simamora, B., 2004. Panduan Riset Perilaku Konsumen, Jakarta: PT Gramedia Pustaka Utama.

Tjiptono, F., 2008.Strategi Pemasaran 3rd ed., Yogyakarta: ANDI.

Tulipa, D. \& Muljani, N., 2015.The Country of Origin and Brand Image Effect on Purchase Intention of Smartphone in Surabaya - Indonesia.Mediterranean Journal of Social Sciences, 6(5), pp.64-70.

Yanthi, K.P. \& Jatra, I.M., 2015. Pengaruh Country Of Origin, Brand Image, dan Perceived Quality terhadap Minat Beli Sepeda Motor Honda Beat di Kota Denpasar. E-Jurnal Manajemen Unud, 4(11), pp.3852-3881. 